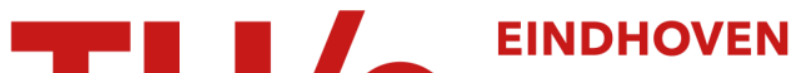 \\ UNIVERSITY OF \\ TECHNOLOGY
}

\section{Research of physical distribution operations}

\section{Citation for published version (APA):}

Tilanus, C. B. (1991). Research of physical distribution operations. European Journal of Operational Research, 50(2), 229-233.

\section{Document status and date:}

Published: 01/01/1991

\section{Document Version:}

Publisher's PDF, also known as Version of Record (includes final page, issue and volume numbers)

\section{Please check the document version of this publication:}

- A submitted manuscript is the version of the article upon submission and before peer-review. There can be important differences between the submitted version and the official published version of record. People interested in the research are advised to contact the author for the final version of the publication, or visit the $\mathrm{DOI}$ to the publisher's website.

- The final author version and the galley proof are versions of the publication after peer review.

- The final published version features the final layout of the paper including the volume, issue and page numbers.

Link to publication

\section{General rights}

Copyright and moral rights for the publications made accessible in the public portal are retained by the authors and/or other copyright owners and it is a condition of accessing publications that users recognise and abide by the legal requirements associated with these rights.

- Users may download and print one copy of any publication from the public portal for the purpose of private study or research.

- You may not further distribute the material or use it for any profit-making activity or commercial gain

- You may freely distribute the URL identifying the publication in the public portal.

If the publication is distributed under the terms of Article 25fa of the Dutch Copyright Act, indicated by the "Taverne" license above, please follow below link for the End User Agreement:

www.tue.nl/taverne

Take down policy

If you believe that this document breaches copyright please contact us at:

openaccess@tue.nl

providing details and we will investigate your claim. 


\title{
Perspectives for Practice
}

\section{Research of physical distribution operations}

\author{
C.B. Tilanus \\ Eindhoven University of Technology, Eindhoven, Netherlands
}

\begin{abstract}
Corporate Forwarding is a corporate staff department of the Philips Group of Industries, Eindhoven, Netherlands. Corporate Forwarding studies physical distribution for the whole of the Philips company and advises the Group Board and individual Product Divisions, like Lighting, Consumer Electronics, Components, Medical Systems. Research activities of Corporate Forwarding are described. It is suggested that research projects of physical distribution operations, whether organizational, economic, informational or mathematical, be considered as Operations Research per se.
\end{abstract}

Keywords: Distribution, professional

\section{Introduction}

Philips International company is based in Eindhoven, centre of the fast expanding south of The Netherlands. Philips has huge central warehouses in neighbouring villages (Veldhoven, Acht).

Corporate Forwarding is a corporate staff department of Philips, located in Eindhoven. In the Charter Corporate Forwarding of 1984 the following is spelled out.

Corporate Forwarding's objective is to contribute to the overall company objectives by supporting logistics strategies in structuring the physical movement of goods in technical, documentary and organizational aspects.

Corporate Forwarding's main tasks can be categorized in the four following areas:

- The bridging between internal and external parties at corporate level, especially in relationship to the transport market and customs and other public authorities. This task of mediation includes

Received June 1990; revised September 1990 policies and principles in terms of credibility and consistency.

- Paving the way so that performance and control of the physical goods flow can succesfully deal with new logistics structures/requirements. This task of conditioning includes the provision of communication standards, codes of conduct, simplification and harmonization, training and management development.

- The structuring and interlinkage of imports/ exports and national physical distribution services in a regional or interregional way on the one hand and between Product Divisions and these services in Philips National Organizations on the other hand. This coordination task aims at full utilization of all expertise and resources in a combined way.

- Acting as a know-how centre, Corporate Forwarding assists in studies and projects of both Product Divisions and National Organizations. This consultancy covers the whole range of functional elements like transport, warehousing, packaging, handling, legislation and data interchange as well as the integral effectiveness of e.g. pipeline architecture. This task also provides the 
company with a platform towards the outside world in the fields concerned.

Generally speaking, Corporate Forwarding's main task is to safeguard the optimal functioning of physical distribution within the company. This is realized through the following activities:

- upkeep and development of the functional area,

- coordination of the Product Divisions,

- consultancy/projects,

- management development,

- education and training,

- auditing.

Consultancy/projects relate to, e.g.,

- determination of the policy and the required infrastructure, procedures, systems and organization;

- evaluation of the performance, formulation and implementation of improvements.

Auditing relates to, e.g.,

- the functioning and the performance of physical distribution service providers;

- the effectivity of the network of services;

- the system interfaces between service providers and concern organizations;

- the usage by concern organizations of the internal service network and other joint resources.

In the description thus far of responsibilities and activities of Corporate Forwarding, which has been quoted in part from the functional specification of Corporate Forwarding, no word has been said about the methodologies and disciplines that Corporate Forwarding is supposed to employ. In fact, one may infer that organizational and business economics skills are needed most.

Is there no hope of applying quantitative methods in such an environment? There is, but to a limited extent. We shall give three examples, one each at the operational, the tactical and the strategic level.

\section{Quantifying product characteristics}

Measuring, or quantifying, product characteristics like relative heaviness or relative value may or may not be included as quantitative methods. We include it. Simple measures can already give helpful insights at the operational level.
Weight historically has been, and often still is, the dimension in which transportation performance is measured. In fact, apart from steel and stone, transportation is mostly constrained by volume. Almost all packaged consumer products are volume-constrained.

The ratio of weight to volume (tonnes : cubic metres $=$ kilogrammes $:$ litres $=$ gross specific gravity) of packaged products is often below $1: 5$ or even $1: 10$. If gross specific gravity of packaged products is less than $\frac{1}{3}$ (or, using the term for the reciprocal, common in transportation: if packaged products 'measure three times' or more) in road transport the freight price will be based on volume (the kilogramme rate will have to be paid for each litre). In air transport, freight price will be based on volume if goods 'measure six times' or more; etc.

Philips ships only volume-constrained products. That is why Corporate Forwarding strongly advocates 'volume-transport': the maximum length, width and height measures on the road and the construction of truck combinations (top-sleepers, short-coupling systems, small tyres - low chassis) such that truck loads of $120 \mathrm{~m}^{3}$ plus are allowed, thereby diminishing the congestion of the infrastructure.

Other ratios are important as well.

The ratio of value to volume ('value density' = value of transported goods per $\mathrm{m}^{3}$ ) has a long-term upward trend. This is especially true in the electronics industry, because of quality improvements and miniaturization. The corollary is, that interest on goods in the transportation pipelines increases relatively to freight prices, so that the optimum

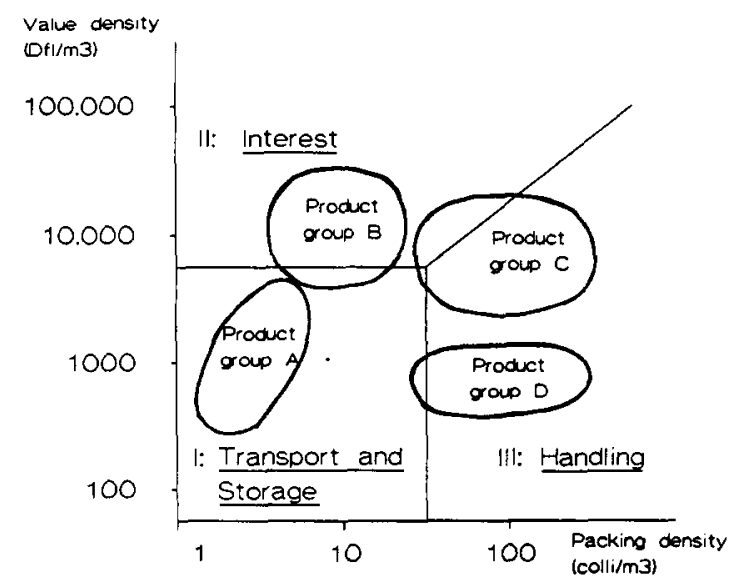

Figure 1. Product groups clustered by value and packing densities 
organization shifts towards more costly transport modes with shorter leadtimes.

The ratio of the number of packages to volume ('packing density' = number of units of transportation per $\mathrm{m}^{3}$ ) shows an upward trend too, because of miniaturization, smaller lot sizes approaching lot size 'one', etc. This ratio determines much of the handling costs (order picking, packaging, reconditioning, stuffing and stripping) in physical distribution.

Products to be shipped may be plotted in a graph by their value and packing densities $[2,4]$, see Figure 1. If products are represented by dots (not shown), it may be possible to cluster groups of products into 'clouds'.

It is then possible to divide the positive quadrant into three area's, I, II and III:

- $I$ is the area of low value and low packing density; physical distribution is mainly concerned with transportation and storage costs (we assume products are voluminous); distribution should be cheap.

- II is the area of high value density; physical distribution is mainly concerned with interest cost of goods in the pipeline; distribution should be fast.

- III is the area of high packing density; physical distribution is mainly concerned with handling costs; distribution should be simple.

\section{Assessing warehouse costs by regression}

Determining the costs of warehousing is not at all easy. Yet the costs must be known to study the distribution structure at the tactical level (opening or closing warehouses, employing or not employing them as warehouses or merely as transshipment points, i.e., with or without storage).

Fortunately, a concern like Philips disposes of enough warehouses to assess their average or standard costs by statistical means $[5,6]$.

The costs of inventory may be classified by the 'three r's':

(1) Room: costs of handling and storage.

(2) Rent: interest cost on the goods stored and in the pipeline.

(3) Risk: cost of a premium to be accounted for the risk of deterioration or obsolescence of the goods stored so that they may not sell at their assessed price.

The costs of warehouses are only the first costs, of 'room'.

There seems to be a logical relation between the costs of warehouses and the volume of inventory turnover (in $\mathrm{m}^{3}$ ). The link between costs of warehouses and the value of inventory turnover seems more indirect. Both regressions were tried and the fit did not differ much.

Figure 2 shows the linear regression of

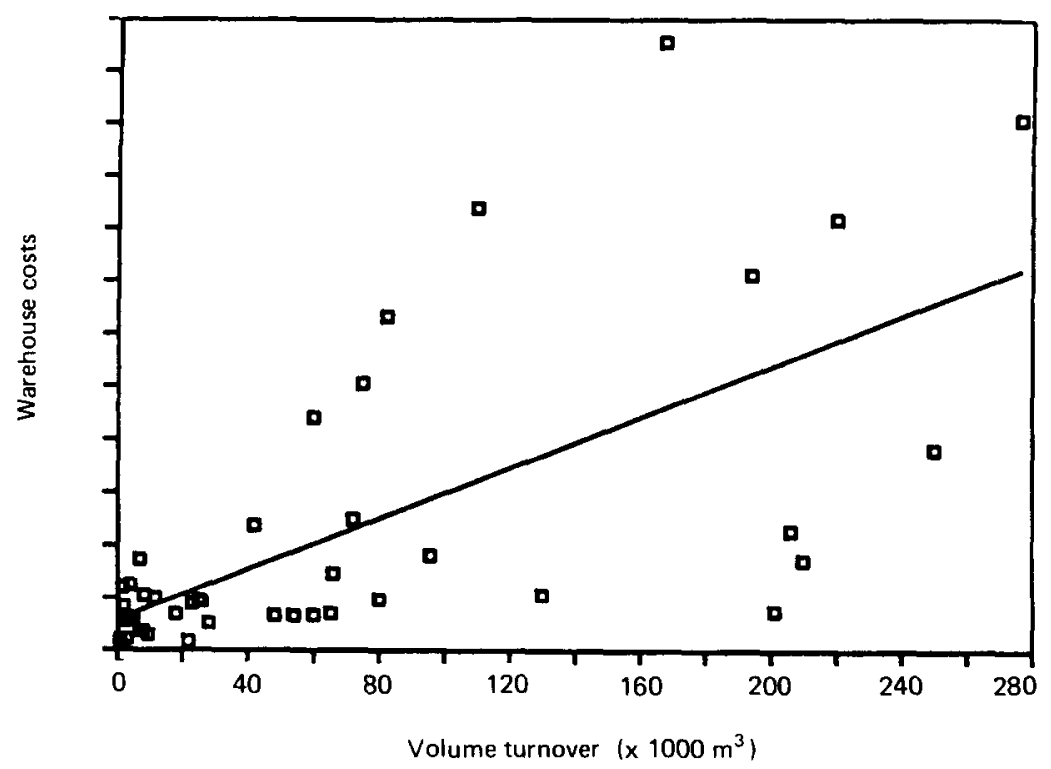

Figure 2. Warehouse costs and volume turnover of 42 European Philips warehouses (vertical scale omitted because of confidentiality) 
warehouse costs on volume turnover. The insight drawn from this picture is that only a small portion of warehouse costs is fixed. Whether you make the warehouses small or large, total warehouse costs can be approximated by proportionally variable costs only, disregarding economies of scale. This fact can play a part in tactical distribution studies.

Of course, the dispersion around the regression line is great. A deviation of individual warehouse costs from the regression value may have three main reasons:

(1) Circumstances: the deviation is caused by given, external factors (e.g. location of the warehouse, mix of the goods processed).

(2) Administration: the costs or turnover have been assessed in an administratively different way (in spite of rigorous Philips standards), the observation is false, the deviation is spurious.

(3) Efficiency: the deviation is real and caused by above- or below-standard operations.

In the latter case, warehouses operating above standard, as well as warehouses operating below standard, may elicit further investigations at the tactical level.

\section{Optimizing the distribution structure}

Using simple simulation or optimization models, at a high level of aggregation, one can try to find the optimum distribution structure for the whole, or parts of a concern, for the whole, or part of the world. Given the long-term qualitative, quantitative and geographic distribution of demand (a heroic assumption), one can try to solve the simultaneous location/allocation problem of determining the optimum flow pattern of goods, the location of warehouses and even the location of production facilities. Such studies are at the strategic level.

In the face of all the uncertainties and the roughness of aggregation, it is rather immaterial whether one tries to optimize with a simulation model or simulate with an optimization model. Praasterink [5] studied the European distribution of Philips consumer products (three product divisions) using an ad hoc, spread-sheet simulation model. Kox [3] studied the European distribution of the Philips product division 'Consumer Electronics' (turnover: $17 \times 10^{9}$ guilders) using a standard simulation software package (called SIMNET). De Bruin [1] studied the European distribution of the Dowanol product group of Dow Chemical company using a mixed-integer linear programming model (and a PC package called VINO).

Non-optimizing, simulation algorithms are of course easier to use in times when there is a trend to close down warehouses and factories than in times when there is a trend to open up new warehouses and factories. The number of possible options to be investigated when closing down is generally much smaller than when opening up.

In fact, there is a trend to close down warehouses and factories for a number of reasons:

- economies of scale in production and warehousing (still);

- cheaper and faster transportation (upsurge of road transportation, lowering of frontier barriers);

- economies in inventories (inventory cost of more valuable inventories kept more centrally at lower total level, sometimes referred to as the 'square root rule').

Another trick to limit the number of possible options is to discretize the distribution of demand

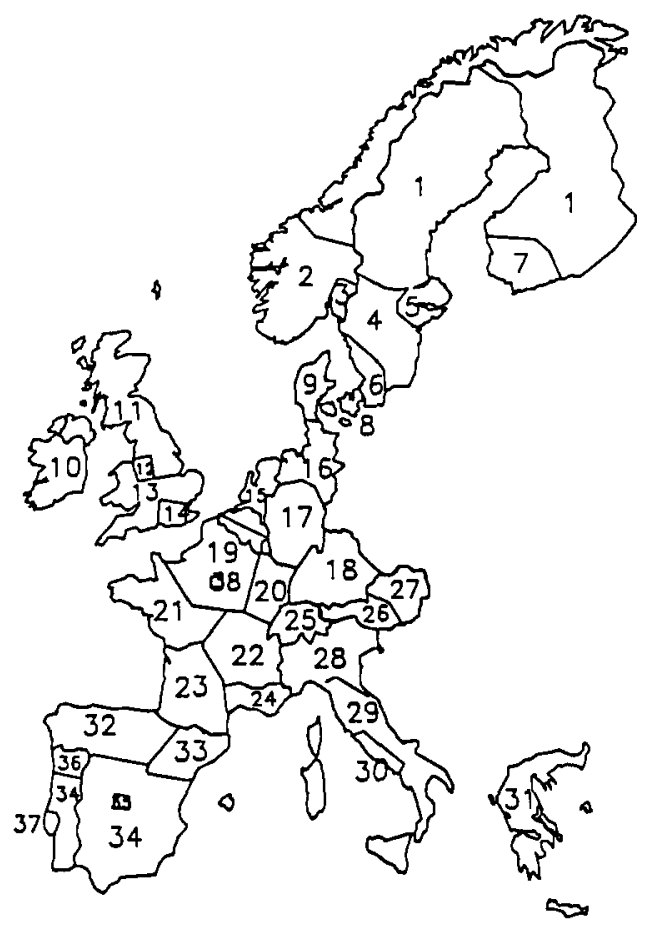

Figure 3. The 38 regions into which European demand for Philips consumer products is split up 
into a set of centres of gravity and to restrict the possible locations of warehouses and factories to this set. Praasterink [5] first split up European demand by population density into 38 regions (see Figure 3). Since only demand at the national level, not at the regional level was known and forecast, he then distributed national demands to the regions in proportion to the regional populations. Finally, he pinpointed demand for each region by taking the capital city or somehow selecting a 'centre of gravity'. The ad hoc heuristic consisted of opening up fictitious warehouses in all 38 points of demand and then closing them down judiciously one by one, until the distribution structure could no longer be improved.

\section{Conclusion}

We have described research activities of the Philips concern department Corporate Forwarding and assessed that quantitative methods can only be applied now and then. Although all the research is focussed on operations in physical distribution in the short, medium as well as long run, it is evidenced that the 'hard' operations research disciplines, mathematics and informatics, are of little use, whereas the 'soft' disciplines, organization theory and economics, are of pivotal importance.

This assessment is in line with an analysis made of 58 Master's projects in physical distribution at the Faculty of Industrial Engineering and Management Science, Eindhoven University of Technology [7]. If key problems are reduced to disciplines needed to be applied to the problems, organization theory contributes 62 per cent, business economics 31 per cent, informatics 4 per cent and mathematics 3 per cent.
Rather than conclude 'this is not operations research', we wish to suggest that the activities described are OR per se. The slogan of OR should be: research of operations is operations research. The OR community should welcome any, new or old, disciplines that can help solve decision making problems in organizations.

\section{References}

[1] Bruin, J.M.M. de, "Dowanol distribution study", unpublished Master's thesis, Eindhoven University of Technology, Eindhoven, 1989.

[2] Goor, A.R. van, Ploos van Amstel, M.J., and Ploos van Amstel, W., Fysieke distributie: Denken in toegevoegde waarde (Physical Distribution: Thinking in Value Added), Stenfert Kroese, Leiden, 1989.

[3] Kox, W.A.J., "Restructuring European physical distribution network Philips Consumer Electronics", unpublished Master's thesis, Eindhoven University of Technology, Eindhoven, 1990.

[4] Ploos van Amstel, M.J., "Produkt karakteristieken en fysieke distributie" (Product characteristics and physical distribution), in: P.M.T. Canals et al., Handboek Goederenstroombesturing (Logistics Handbook), Samsom, Alphen a/d. Rijn, 1985.

[5] Praasterink, T.F., "Structuurontwerp internationale fysieke distributie" (Designing international physical distribution structure), unpublished Master's thesis, Eindhoven University of Technology, Eindhoven, 1989.

[6] Praasterink, T.F., and Tilanus, C.B., "De fysieke distributie-structuur voor Superchip" (The physical distribution structure for Superchip), unpublished case study, Eindhoven University of Technology, Eindhoven, 1990.

[7] Tilanus, C.B., "Welke distributielogistieke onderzoekthema's draagt het bedrijfsleven aan?" (What distribution logistics research topics are proposed by business?), in: $\mathbf{R}$. Hamerslag and A.J.H. Weenink (eds.), Bijdragen Vervoerslogistieke Werkdagen 1989 (Contributions to Transport Logistics Workshop 1989), EVO, Zoetermeer, 1989. 